\title{
Remote Sensing for Vegetation and Climate Change
}

\section{Mukesh Singh Boori* and Komal Choudhary}

Palacky University Olomouc, 17.listopadu 50, 77146 Olomouc, Czech Republic

Our empathetic about how climate change will impact on natural vegetation are based on earlier research studies related to climate change, current observation of variation in climate change, some experiments and model simulation. Other than this, the change in temperature and precipitation is also affected the composition, structure and function of ecosystem. Changes in vegetation in response to climate change have begun to be observed within remote sensing datasets, particularly within more climatically extreme regions. Earlier studies find changes in growing season and productive with the help of remote sensing data. At the other end of the temperature spectrum, the Normalized Difference Vegetation Index (NDVI) has been widely used to evaluate the response of vegetation and precipitation. Warming climate, in contrast to other studies, has not promoted vegetation growth in the spring; instead, the greenness displayed a decrease in May and June. Although this seasonal browning is associated with human management, limited water availability in late spring and early summer is likely the root cause and ongoing warming would likely exacerbate this seasonal moisture shortage. For the desert steppe, a negative response of NDVI to increased temperature in both spring and autumn, and the conservation program seems to have produced few positive effects [1-10]. This result suggests that desert steppe will possibly be the most fragile vegetation type in a warmer world. The warming in this century differs from the warmer climate during the early and middle Holocene with respect to magnitude and seasonality, both of which would be not favourable to the vegetation in the future. Even if a much more intense rehabilitation effort is envisioned, it is unlikely that a reoccurrence of mid- Holocene vegetation cover levels will occur in the temperate dry lands of East Asia under current warming trends. The temperature and precipitation regimes under which tree species are currently able to establish and survive have been well described in the north-western United States, Europe and tropical ecosystems. These regimes have been used to predict how the distributions of individual tree species will be influenced by future climate using both correlative and quasi-mechanistic approaches. Several recent reviews have highlighted how anthropogenic changes in climate are likely to affect the biogeography and structure of different ecosystems, including Australian ecosystems, European forests, North American forests, boreal and arctic systems, semi-arid and arid riparian zones and coastal ecosystems. Specifically, a recent expert panel identified ten Australian ecosystems that they judged to be the most vulnerable to exhibiting large changes in ecosystem structure, condition, and function in response to small environmental changes [11-18]. These ecosystems included: mountainous environments, temperate eucalypt forests, tropical forests and savannahs, Mediterranean and semi-arid lands, floodplains and wetlands, and coral reefs. In Europe, Schroter et al. highlighted that Mediterranean and mountainous ecosystems were particularly vulnerable.

\section{References}

1. Boori MS, Choudhary K, Kupriyanov A (2015) City susceptibility and sustainable development in southeast asia. Journal of Earth Science and Climate Change 6: 01-03.

2. Boori MS, Vozenilek V, Choudhary K (2015) Land use/cover disturbances due to tourism in Jeseniky Mountain, Czech Republic: A remote sensing and GIS based approach. The Egyptian Journal of Remote Sensing and Space Sciences 17: 01-10.
3. Boori MS, Vozenilek V, Balzter H, Choudhary K (2015) Land surface temperature with land cover classes in ASTER and Landsat data. Journal of Geophysics and Remote Sensing 4: 01-03.

4. Boori MS, Netzband M, Vozenilek V, Choudhary K (2015) Urbanization analysis through remote sensing and GIS in Kuala Lumpur, Manila and Singapore cities. Recent Advances in Electrical Engineering 42: 99-110.

5. Boori MS, Ferraro RR (2015) Global Land Cover classification based on microwave polarization and gradient ratio (MPGR). Geo-informatics for Intelligent Transportation. Springer International Publishing Switzerland 71: $17-37$.

6. Boori MS, Vozenilek V, Choudhary K (2015) Land Use/Cover Change and Vulnerability Evaluation in Olomuc, Czech Republic, ISPRS Ann Photogramm Remote Sens Spatial Inf Sci, II-8, 77-82

7. Choudhary K, Boori MS, Novacek P (2014) A multi-criteria approach: for empowerment to enhancing community sustainable development. JGRS 3 01-04.

8. Choudhary K, Boori MS (2014) Earth science and climate change in concern of Socio-economics. JESCC 5: 01-01.

9. Boori MS, Vozenilek V (2014) Land-cover disturbances due to tourism in Jeseniky mountain region: A remote sensing and GIS based approach. SPIE Remote Sensing. 9245: 01-11.

10. Boori MS, Vozenilek V (2014) Socio-hydrological vulnerability: A new science through remote sensing and GIS. Global journal of Researches in Engineering: E Civil and Structural Engineering 1436: 42.

11. Boori MS, Vozenilek V, Balzter H (2014) Satellite datasets and there scaling factor for land surface temperature. JGG 3: 01

12. Boori MS, Vozenilek V (2014) Assessing land cover change trajectories in Olomouc, Czech Republic. International journal of Environmental, Ecology, Geological and Mining Engineering 8: 540-546.

13. Boori MS (2014) Earth science and climate change overview in context of human and natural causes. JESCC 5: 01-02.

14. Boori MS, Ferraro RR, Vozenilek V(2014) NASA EOS Aqua Satellite AMSR-E data for snow variation. JGG 3: 01-06.

15. Boori MS, Vozenilek V (2014) Remote Sensing and land use/land cover trajectories. Journal of Geophysics and Remote Sensing 3: 01-07.

16. Boori MS, Vozenilek V, Burian J (2014) Land-cover disturbances due to tourism in Czech Republic. Advances in Intelligent Systems and Computing,Springer International Publishing Switzerland 303: 63-72.

17. Boori MS, Vozenilek V (2014) Land use/cover, vulnerability index and exposer intensity. Journal of Environments1: 01-07.

18. Schröter D, Cramer W, Leemans R, Prentice IC, Araújo MB, et al. (2005) Ecosystem service supply and vulnerability to global change in Europe. Science 310: 1333-1337.

*Corresponding author: Mukesh Singh Boori, Palacky University Olomouc, 17.listopadu 50, 77146 Olomouc, Czech Republic, Tel: 0123456789; E-mail: Komal.kc06@gmail.com,msboori@gmail.com

Received March 17, 2015; Accepted March 19, 2015; Published March 26, 2015

Citation: Boori MS, Choudhary K (2015) Remote Sensing for Vegetation and Climate Change. J Remote Sensing \& GIS 4: e111. doi:10.4172/24694134.1000e111

Copyright: @ 2015 Boori MS, et al. This is an open-access article distributed under the terms of the Creative Commons Attribution License, which permits unrestricted use, distribution, and reproduction in any medium, provided the original author and source are credited. 